\title{
Starches from non - conventional sources to improve the technological characteristics of pound cake
}

\author{
Amido de fontes não - convencionais para melhorar as características tecnológicas de bolo inglês
}

\author{
Eveline Lopes Almeida ${ }^{\mathrm{I}}$ André Luis Marangoni ${ }^{\mathrm{I}}$ Caroline Joy Steel ${ }^{\mathrm{I}^{*}}$
}

\section{ABSTRACT}

This study evaluated and compared the effect of the utilization of five different non-conventional starches (chickpea, common bean, Peruvian carrot, sweet potato and white bean) and four different commercial starches (cassava, corn, potato and rice) in pound cake. Common bean starch, followed by Peruvian carrot starch were the non-conventional starch sources that showed tendency to improve the technological quality of pound cake, mainly in relation to corn starch, the most common commercial source. With these sources, the batters presented lower specific gravity and the cakes presented higher specific volume, lighter color, lower crumb moisture reduction during the storage period, and better texture attributes during all the cake shelf-life. Moreover, common bean starch provided higher scores in the cake sensory evaluation; especially for grain and texture attributes (moisture, tenderness and softness). Chickpea and white bean starches were more similar to corn starch in pound cake application.

Key words: bean, chickpea, Peruvian carrot, potato, cassava, starch, pound cake.

\section{RESUMO}

Este estudo avaliou e comparou o efeito da utilização de cinco amidos de fontes não convencionais (grão de bico, feijão carioca, mandioquinha, batata doce e feijão branco) e de quatro diferentes amidos de fontes comerciais (mandioca, milho, batata e arroz) em bolo inglês. Amido de feijão carioca, seguido pelo amido de mandioquinha, foram os amidos de fontes não convencionais que mostraram tendência a melhorar a qualidade tecnológica do bolo inglês, principalmente em comparação com o amido de milho, o qual é a fonte comercial mais utilizada. Com o amido dessas fontes, os batidos apresentaram menores valores de gravidade específica e os bolos maiores valores de volume específico, cor mais clara, menor redução da umidade durante o período de estocagem e melhores valores nos atributos de textura durante a vida de prateleira. Além disso, amido de feijão carioca promoveu maiores escores na avalição sensorial; especialmente para os atributos do miolo e textura (umidade, suavidade e maciez). Amidos de grão de bico e feijão branco foram muito similares ao amido de milho em aplicação em bolo inglês.

Palavras-chave: feijão, grão de bico, mandioquinha, batata, mandioca, amido, bolo inglês.

\section{INTRODUCTION}

Cakes and breads are the products that have the highest consumption rate among baked goods (SOZER et al., 2011a). Cake quality is affected by the ingredients used in an appropriate and properly balanced formulation, and mixing and baking procedures (TIREKI, 2008). Many types of flours are available for the production of cakes and it is important that sufficient attention is given to choose the correct type for the process. For sponge goods, a soft flour should be used and, in some types of goods, a proportion of corn starch is sometimes added to make the flour softer and produce articles of a better texture (BENNION \& BAMFORD, 1997).

The development of cake structure starts in the mixing stage, through the incorporation of air cells in the system and continues in the baking stage, through the conversion of the aerated emulsion of the cake batter to a product with a semisolid porous structure and a soft crumb. Final product texture is set by starch gelatinization and protein coagulation during baking (SAHIN, 2008). During the initial phase of baking, there is a drop in batter viscosity as

IDepartamento de Tecnologia dos Alimentos, Faculdade de Engenharia dos Alimentos, Universidade Estadual de Campinas (UNICAMP), Campinas, SP, Brasil. E-mail: cjsteel@yahoo.com. *Autor para correspondência. 
shortening melts and sugars become dissolved. This is followed by a rapid rise in viscosity when starch becomes gelatinized, absorbing free water and setting the cake (HOWARD et al., 1968; SHELKE et al., 1990).

Therefore, starch is one of the components responsible for the structure and final result of cakes. HOWARD et al. (1968) evaluated the utilization of various types of unmodified granular starches (wheat, corn, potato, rice, arrowroot, waxy rice) in high-sugar batters. They concluded that the variation in performance was due to the gelatinization properties of the various starch samples. In addition to influencing structure, starch can influence other cake characteristics, as its susceptibly to staling can be related to starch retrogradation, especially amylopectin retrogradation, and to gluten-starch interactions (LAI \& LIN, 2006).

In view of above, the objective of this study was to evaluate and compare the effect of the utilization of different non-conventional (chickpea, common bean, Peruvian carrot, sweet potato and white bean) and commercial (cassava, corn, potato and rice) starches on the technological characteristics of pound cake.

\section{MATERIAL AND METHODS}

The starches from non-conventional sources (chickpea, common bean, Peruvian carrot, sweet potato, and white bean) used for cake preparation were extracted in the laboratory, as described below. The commercial starches used were Melojel native corn starch (National Starch \& Chemical, Trombudo Central, Brazil), Amilogill 1500 cassava starch (Cargill, São Paulo, Brazil), Avebe potato starch (Avebe do Brasil Ltda, São Paulo, Brazil), Amitec 100 rice flour (Amitec Indústria e Comércio de Amidos Ltda, Goioerê, Brazil). The other ingredients used for cake production (wheat flour, refined sugar, margarine, skimmed milk powder, baking powder, salt and eggs) were obtained in the local market.

Peruvian carrot and sweet potato, previously selected, were passed through a conveyor belt and received an aspersion of chlorinated water. They were then peeled by abrasion, cut in cubes and immersed in a $0.01 \%$ solution of sodium metabisulphite. Chickpea, common bean and white bean, also previously selected, were macerated in a $0.01 \%$ solution of sodium metabisulphite for $24 \mathrm{~h}$. All these raw-materials were crushed through chopper knives and ground in a depulper, where part of the fibers were eliminated. The fibers that remained were removed by passing the starch milk through a $70 \mu \mathrm{m}$ sieve. The starch milk was left to rest for $24 \mathrm{~h}$ at $8^{\circ} \mathrm{C}$ and the separation of protein from starch was then carried out using a hydrocyclone. The underflow obtained was left to rest for $3 \mathrm{~h}$. The supernatant was removed and the sedimented starch was dried in an oven at $45^{\circ} \mathrm{C}$ for $48 \mathrm{~h}$. To reduce particle size, the starch was ground in a hammer mill.

The formulation used for cake preparation was wheat flour $(29.77 \%)$, refined sugar $(25.60 \%)$, water $(17.83 \%)$, eggs $(11.38 \%)$, margarine $(9.96 \%)$, starch $(2.98 \%)$, skimmed milk powder $(1.42 \%)$, baking powder $(0.64 \%)$ and salt $(0.42 \%)$. The batters were prepared in a Hobart 34 mixer (SiamUtil S/A, São Paulo, Brazil). For each formulation, a $5 \mathrm{~kg}$ batch was prepared. Margarine and sugar were mixed during $1 \mathrm{~min}$ at slow speed; then eggs were added and mixed for $5 \mathrm{~min}$ at high speed. Half of the water was added and mixed with the cream for $5 \mathrm{~min}$ at slow speed. Wheat flour, starch, skimmed milk powder and salt (previously homogenized) and the remaining half of water were added to the cream and mixed for $1 \mathrm{~min}$ at slow speed. At the end, the baking powder was added and mixed for $2 \mathrm{~min}$ at slow speed. The batter $(400 \mathrm{~g})$ was put in pound cake pans and was baked in a Hyppo HF4B oven (Hyppolito, Ferraz de Vasconcelos, Brazil) for $35 \mathrm{~min}$ at $160^{\circ} \mathrm{C}$. The cakes were left for $1 \mathrm{~h}$ at room temperature for cooling. Then, they were packed in polypropylene bags and stored at room temperature in a dry place until analyses.

Batter density was evaluated according to AACC Method 55-50.01 (AACC, 2010). Cake apparent volume was determined by rapeseed displacement using AACC Method 10-05.01 (AACC, 2010), and cake mass, using a semi-analytical scale. Specific volume was determined through the volume/ mass ratio and expressed in $\mathrm{mL} \mathrm{g}^{-1}$. Volume, symmetry and uniformity indexes of cakes were determined in accordance with AACC Method 10-91.01 (AACC, 2010). Crumb color was evaluated in the center of the sliced cake, using a Color Quest II colorimeter (Minolta Camera Co., Osaka, Japan), with an observation angle of $10^{\circ}$ and D65 illuminant. The CIEL*a*b* system was used, where: L* (black 0/white 100), a* (green -/red + ) and $b^{*}$ (blue -/yellow + ). Sensory analysis was carried out in accordance to AACC Method 1090.01 (AACC, 2010) by 12 untrained panelists. For the monitoring of the cakes during the six-day storage period, crumb moisture determination and texture profile analysis (TPA) of cakes were carried out on the second, fourth and sixth days after cake processing. Crumb moisture was evaluated through AACC 
Method 44-10.01 (AACC, 2010). Texture profile analysis (TPA) was determined in a texture analyzer, TA-XT2i (Stable Micro Systems, Surrey, UK), using a P/100 aluminum probe (compression platens of $100 \mathrm{~mm}$ diameter) and the following parameters: measurement of force in compression; pre-test speed $=$ $5.0 \mathrm{~m} \mathrm{~s}^{-1}$; test speed $=2.0 \mathrm{~m} \mathrm{~s}^{-1}$; post-test speed $=5.0 \mathrm{~m}$ $\mathrm{s}^{-1} ;$ force $=20 \mathrm{~g}$; cycle count $=5 \mathrm{~s}$ and trigger force $=$ $10 \mathrm{~g}$. The texture attributes evaluated were: hardness, springiness, cohesiveness, gumminess, chewiness and resilience. For instrumental texture determination, cakes were previously sliced with an electric slicer into $1.25 \mathrm{~cm}$ thick slices. The evaluation was carried out through compression of the probe on two central slices, disposed horizontally on the platform.

All analyses were carried out in three replicates, except texture profile analysis, which was carried out in six replicates. The data collected was subjected to analysis of variance (ANOVA) and the Tukey test using the SAS program for Windows V8 (SAS Institute Inc., Cary, USA). Least significant differences at $\mathrm{P}<0.05$ were used to compare sample means.

\section{RESULTS AND DISCUSSION}

\section{Batter specific gravity and cake specific volume}

Amongst conventional starch sources (cassava, corn, potato and rice), no significant differences were found for their effect on specific gravity (Table 1). Batters prepared with common bean and Peruvian carrot starches presented the lowest values for specific gravity, diverging from other batters. A low value for specific gravity is usually desirable, indicating greater air incorporation by the batter (AIB, 2001). Specific gravity of batters made with non-conventional starch sources such as sweet potato, white bean, and cassava did not differ from corn starch, a more commonly used conventional starch source. Chickpea starch provided lower specific gravity than corn starch. The values of specific volume ranged from $1.77 \mathrm{~mL} \mathrm{~g}^{-1}$ for the cakes formulated with corn starch to $2.48 \mathrm{~mL} \mathrm{~g}^{-1}$ for the cakes formulated with common bean starch. In this case, the lowest batter density reflected in the highest specific volume. A good-quality cake should have high volume (SOZER et al., 2011b). Cassava and Peruvian carrot starches provided cakes with specific volume that did not differ from cakes elaborated with corn starch. Starches from other non-conventional sources such as sweet potato, white bean, common bean and chickpea provided higher specific volumes than cakes made with the conventional sources corn and rice starches. The legume, root and tuber starches provided higher specific volumes than the cereal starches. In general, an inverse relationship between batter density and cake specific volume was not observed.

Volume, symmetry and uniformity indices

The values for volume, symmetry and uniformity indices were very close to one another (Table 1). Therefore, no significant differences $(\mathrm{P}<0.05)$ were observed among the cakes prepared with the different starch sources, considering all indices. This shows that, independent of the starch source used, it did not interfere in these indices, which are evaluations of external measurements of the cakes. In general, cakes presented good values for these indices. For volume index, the values ranged between 17.1 and $18.2 \mathrm{~cm}$. According to GÓMEZ et al. (2008), the volume index is an indicator of cake volume and follows a similar tendency as volume. However, this similar tendency was not obtained. Differences in the volume index were not found among the cakes, whereas differences in the specific volume were observed. The symmetry index values ranged between 1.1 and $2.8 \mathrm{~cm}$. This shows that the cake center was slightly higher than its extremities. In other words, the cakes showed a slight elevation on the superior part, which is characteristic of pound cakes due to the opening that occurs in the top center of the cake. The uniformity index ranged between 0 and $0.4 \mathrm{~cm}$. Due to the low value presented by this index, it was observed that the two extremities of the cake showed similar or the same height.

Instrumental color

The cakes formulated with cassava, corn, potato and rice starches did not differ statistically between each other for all color parameters (Table 1). It demonstrates the similarity of cake instrumental color provided by the commercial starch sources studied. The cakes formulated with white bean, common bean and chickpea starches differed statistically from the cake formulated with corn starch in relation to all color parameters. These cakes formulated with these nonconventional sources tended to be lighter (higher L*), less red (lower $\mathrm{a}^{*}$ ) and less yellow (lower $\mathrm{b}^{*}$ ) in relation to the cake formulated with corn starch. These starch sources are an option to formulators who wish a lighter cake color. The cake formulated with sweet potato starch only differed from the cake formulated with corn starch in relation to $\mathrm{a}^{*}$. The cake formulated with sweet potato starch tended to a more red color (higher $a^{*}$ value) than the cake formulated with corn starch. Therefore, sweet potato starch would be the starch from the non- 
Table 1 - Physical properties of the batter and cakes prepared with starches from different sources.

\begin{tabular}{|c|c|c|c|}
\hline Starch Source & Batter Specific Gravity & \multicolumn{2}{|c|}{ Specific Volume $\left(\mathrm{mL} \mathrm{g}^{-1}\right)$} \\
\hline Cassava & $1.13 \pm 0^{\mathrm{a}}$ & \multicolumn{2}{|c|}{$2.05 \pm 0.05^{\mathrm{ab}}$} \\
\hline Corn & $1.12 \pm 0^{\mathrm{ab}}$ & \multicolumn{2}{|c|}{$1.77 \pm 0.06^{\mathrm{b}}$} \\
\hline Potato & $1.09 \pm 0.01^{\mathrm{abc}}$ & \multicolumn{2}{|c|}{$2.18 \pm 0.05^{\mathrm{a}}$} \\
\hline Rice & $1.10 \pm 0.01^{\mathrm{abc}}$ & \multicolumn{2}{|c|}{$1.78 \pm 0.11^{\mathrm{b}}$} \\
\hline Chickpea & $1.06 \pm 0.02^{\mathrm{c}}$ & \multicolumn{2}{|c|}{$2.41 \pm 0.16^{\mathrm{a}}$} \\
\hline Common bean & $1.00 \pm 0.01^{\mathrm{d}}$ & \multicolumn{2}{|c|}{$2.48 \pm 0.07^{\mathrm{a}}$} \\
\hline Peruvian carrot & $1.00 \pm 0.02^{\mathrm{d}}$ & \multicolumn{2}{|c|}{$2.12 \pm 0.33^{\mathrm{ab}}$} \\
\hline Sweet potato & $1.09 \pm 0.02^{\mathrm{bc}}$ & \multicolumn{2}{|c|}{$2.26 \pm 0.22^{\mathrm{a}}$} \\
\hline White bean & $1.11 \pm 0.01^{\mathrm{ab}}$ & \multicolumn{2}{|c|}{$2.45 \pm 0.04^{\mathrm{a}}$} \\
\hline Starch Source & Volume $(\mathrm{cm})$ & Symmetry $(\mathrm{cm})$ & Uniformity $(\mathrm{cm})$ \\
\hline Cassava & $18.1 \pm 0.7^{\mathrm{a}}$ & $1.5 \pm 0.8^{\mathrm{a}}$ & $0.4 \pm 0.6^{\mathrm{a}}$ \\
\hline Corn & $18.0 \pm 0.4^{\mathrm{a}}$ & $1.7 \pm 0.4^{\mathrm{a}}$ & $0.1 \pm 0.4^{\mathrm{a}}$ \\
\hline Potato & $17.1 \pm 0.9^{\mathrm{a}}$ & $2.0 \pm 1.0^{\mathrm{a}}$ & $0.3 \pm 0.9^{\mathrm{a}}$ \\
\hline Rice & $17.9 \pm 0.2^{\mathrm{a}}$ & $1.5 \pm 0.3^{\mathrm{a}}$ & $0.4 \pm 0.2^{\mathrm{a}}$ \\
\hline Chickpea & $18.2 \pm 0.5^{\mathrm{a}}$ & $1.6 \pm 0.5^{\mathrm{a}}$ & $0 \pm 0.5^{\mathrm{a}}$ \\
\hline Common bean & $18.1 \pm 0.4^{\mathrm{a}}$ & $2.8 \pm 0.4^{\mathrm{a}}$ & $0.1 \pm 0.4^{\mathrm{a}}$ \\
\hline Peruvian carrot & $17.6 \pm 0.6^{\mathrm{a}}$ & $1.6 \pm 0.6^{\mathrm{a}}$ & $0 \pm 0.6^{\mathrm{a}}$ \\
\hline Sweet potato & $17.2 \pm 0.4^{\mathrm{a}}$ & $2.4 \pm 0.4^{\mathrm{a}}$ & $0.2 \pm 0.3^{\mathrm{a}}$ \\
\hline White bean & $17.5 \pm 0.4^{\mathrm{a}}$ & $1.1 \pm 0.6^{\mathrm{a}}$ & $0.2 \pm 0.3^{\mathrm{a}}$ \\
\hline Starch Source & L* & $\begin{array}{l}\text { a* } \\
\text { a }\end{array}$ & $b^{*}$ \\
\hline Cassava & $78.06 \pm 0.76^{\mathrm{abc}}$ & $1.57 \pm 0.03^{\mathrm{b}}$ & $26.48 \pm 0.03^{\mathrm{a}}$ \\
\hline Corn & $77.76 \pm 0.79^{\mathrm{cd}}$ & $1.52 \pm 0.10^{\mathrm{bc}}$ & $26.61 \pm 0.16^{\mathrm{a}}$ \\
\hline Potato & $78.80 \pm 0.10^{\mathrm{bc}}$ & $1.35 \pm 0.11^{\text {bcde }}$ & $26.36 \pm 0.43^{\mathrm{a}}$ \\
\hline Rice & $77.92 \pm 0.39^{\mathrm{abcd}}$ & $1.45 \pm 0.03^{\mathrm{bcd}}$ & $26.28 \pm 0.46^{\mathrm{ab}}$ \\
\hline Chickpea & $79.91 \pm 0.67^{\mathrm{ab}}$ & $1.19 \pm 0.10^{\mathrm{e}}$ & $24.68 \pm 0.21^{\mathrm{c}}$ \\
\hline Common bean & $80.44 \pm 0.63^{\mathrm{a}}$ & $1.23 \pm 0.12^{\mathrm{de}}$ & $23.52 \pm 0.22^{\mathrm{d}}$ \\
\hline Peruvian carrot & $80.67 \pm 0.07^{\mathrm{a}}$ & $1.30 \pm 0.11^{\text {cde }}$ & $23.01 \pm 0.40^{\mathrm{d}}$ \\
\hline Sweet potato & $75.87 \pm 1.15^{\mathrm{d}}$ & $2.14 \pm 0.07^{\mathrm{a}}$ & $26.86 \pm 0.27^{\mathrm{a}}$ \\
\hline White bean & $80.29 \pm 0.38^{\mathrm{a}}$ & $1.28 \pm 0.05^{\mathrm{de}}$ & $25.40 \pm 0.34^{\mathrm{bc}}$ \\
\hline Starch Source & Day 2 & $\begin{array}{l}\text { Day } 4 \\
\text {---Moisture--- }\end{array}$ & Day 6 \\
\hline Cassava & $29.81 \pm 0.43^{\mathrm{aA}}$ & $26.85 \pm 0.62^{\mathrm{aB}}$ & $24.55 \pm 0.21^{\mathrm{abC}}$ \\
\hline Corn & $30.17 \pm 1.02^{\mathrm{aA}}$ & $26.93 \pm 0.44^{\mathrm{aB}}$ & $25.27 \pm 0.84^{\mathrm{aC}}$ \\
\hline Potato & $29.15 \pm 1.13^{\mathrm{aA}}$ & $26.75 \pm 1.54^{\mathrm{aAB}}$ & $24.61 \pm 0.51^{\mathrm{abB}}$ \\
\hline Rice & $29.95 \pm 2.05^{\mathrm{aA}}$ & $23.68 \pm 1.02^{\mathrm{bB}}$ & $24.75 \pm 0.39^{\mathrm{abB}}$ \\
\hline Chickpea & $29.79 \pm 0.67^{\mathrm{aA}}$ & $25.38 \pm 0.39^{\mathrm{abB}}$ & $24.02 \pm 0.29^{\mathrm{abC}}$ \\
\hline Common bean & $30.18 \pm 0.43^{\mathrm{aA}}$ & $26.84 \pm 0.58^{\mathrm{aB}}$ & $25.56 \pm 0.57^{\mathrm{aC}}$ \\
\hline Peruvian carrot & $31.31 \pm 0.43^{\mathrm{aA}}$ & $26.41 \pm 1.23^{\mathrm{abB}}$ & $24.49 \pm 0.88^{\mathrm{abB}}$ \\
\hline Sweet potato & $30.13 \pm 0.26^{\mathrm{aA}}$ & $24.62 \pm 0.42^{\mathrm{abB}}$ & $23.39 \pm 0.79^{\mathrm{bC}}$ \\
\hline White bean & $29.12 \pm 1.79^{\mathrm{aA}}$ & $25.81 \pm 1.55^{\mathrm{abB}}$ & $24.55 \pm 0.83^{\mathrm{abB}}$ \\
\hline
\end{tabular}

* Mean \pm standard deviation, $\mathrm{n}=3$. Means followed by the same lower case letter on the same column for the same parameter do not differ by the Tukey test $(\mathrm{P}<0.05)$. Means followed by the same upper case letter on the same row for moisture do not differ by the Tukey test $(\mathrm{P}<0.05)$.

conventional sources more similar to corn starch in cake application in relation to instrumental color.

\section{Sensory evaluation}

The mean scores given by the panelists in the sensory evaluation of the cakes are presented in table 2. All the cakes were well evaluated. The cakes prepared with chickpea, common bean, corn, Peruvian carrot, potato and rice starches were the best evaluated cakes according to the sensory panel. The cake elaborated with common bean obtained a higher total score mainly because of the higher scores for 
grain and texture attributes (moisture, tenderness and softness). The cake elaborated with white bean obtained lower scores for cells (uniformity and thickness of walls) and crumb color attributes. The cake elaborated with sweet potato also had lower scores for these attributes and also for texture attributes (tenderness and softness). The sensory panel did not verify significant differences between the cakes elaborated with all the starch sources studied in the attributes size of cell, grain and flavor. The cakes prepared with the commercial sources (corn, cassava, potato and rice) did not present significant differences among themselves in all the attributes evaluated, except in the attribute uniformity of cells. In this attribute, the cake elaborated with potato starch was better than the cakes elaborated with corn and rice starches.

Crumb moisture

The crumb of cakes presented a tendency to lose moisture during storage (Table 1). The cakes were packed in polypropylene bags. Thus, a migration of moisture from crumb to crust possibly occurred. There was a gradual reduction of moisture from day 2 to day 6 in the crumb of cakes elaborated with all starches sources. This reduction tends to be lower in the cakes elaborated with Peruvian carrot, potato, rice and white bean starches. In these cakes, crumb moisture found on day 6 did not differ from crumb moisture found on day 4. This shows that these starch sources tended to retain crumb moisture until the sixth day of storage. On the second day of shelf-life, the cakes elaborated with the different starch sources did not present statistical differences for crumb moisture. On the fourth and sixth days of shelflife, the differences for crumb moisture were small. Comparing with the cake elaborated with corn starch (most used commercial source), the only cakes that presented a statistical difference were the cake elaborated with potato starch on the fourth day and the cake elaborated with sweet potato starch on the sixth day. The moisture of these cakes was lower in relation to the cake elaborated with corn starch.

Texture profile analysis (TPA)

With the increase of storage time, a tendency of an increase of hardness and chewiness,

Table 2 -Sensory evaluation scores of cakes prepared with starches from different sources.

\begin{tabular}{|c|c|c|c|c|c|c|}
\hline \multirow{2}{*}{ Starch Source } & \multicolumn{3}{|c|}{ 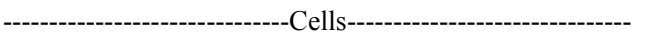 } & \multicolumn{3}{|c|}{ - } \\
\hline & Uniformity & Size & Thickness of walls & Moistness & Tenderness & Softness \\
\hline Cassava & $6.7 \pm 2.9^{\mathrm{ab}}$ & $8.7 \pm 1.8^{\mathrm{a}}$ & $8.3 \pm 2.7^{\mathrm{ab}}$ & $6.8 \pm 1.8^{b}$ & $11.0 \pm 2.5^{\mathrm{ab}}$ & $6.5 \pm 2.7^{b}$ \\
\hline Corn & $5.7 \pm 3.6^{\mathrm{b}}$ & $6.7 \pm 2.1^{\mathrm{a}}$ & $8.0 \pm 2.7^{\mathrm{ab}}$ & $7.3 \pm 1.8^{\mathrm{ab}}$ & $12.3 \pm 1.4^{\mathrm{ab}}$ & $7.8 \pm 2.0^{\mathrm{ab}}$ \\
\hline Potato & $9.7 \pm 1.2^{\mathrm{a}}$ & $8.7 \pm 1.3^{\mathrm{a}}$ & $10.0 \pm 0^{\mathrm{a}}$ & $8.3 \pm 1.7^{\mathrm{ab}}$ & $12.7 \pm 1.8^{\mathrm{ab}}$ & $8.0 \pm 2.6^{\mathrm{ab}}$ \\
\hline Rice & $6.3 \pm 3.2^{\mathrm{b}}$ & $8.3 \pm 1.7^{\mathrm{a}}$ & $8.7 \pm 2.6^{\mathrm{ab}}$ & $8.8 \pm 1.3^{\mathrm{ab}}$ & $12.5 \pm 1.5^{\mathrm{ab}}$ & $8.5 \pm 1.7^{\mathrm{ab}}$ \\
\hline Chickpea & $6.0 \pm 2.4^{\mathrm{b}}$ & $7.0 \pm 2.0^{\mathrm{a}}$ & $7.7 \pm 2.1^{\mathrm{ab}}$ & $8.0 \pm 2.1^{\mathrm{ab}}$ & $12.2 \pm 2.9^{\mathrm{ab}}$ & $7.7 \pm 2.4^{\mathrm{ab}}$ \\
\hline Common bean & $7.7 \pm 2.7^{\mathrm{ab}}$ & $7.7 \pm 1.9^{\mathrm{a}}$ & $9.7 \pm 1.2^{\mathrm{a}}$ & $9.3 \pm 2.7^{\mathrm{a}}$ & $13.3 \pm 1.3^{\mathrm{a}}$ & $9.5 \pm 1.7^{\mathrm{a}}$ \\
\hline Peruvian carrot & $7.3 \pm 3.1^{\mathrm{ab}}$ & $7.7 \pm 1.7^{\mathrm{a}}$ & $9.7 \pm 1.2^{\mathrm{a}}$ & $8.2 \pm 2.0^{\mathrm{ab}}$ & $13.3 \pm 1.3^{\mathrm{a}}$ & $9.2 \pm 1.8^{\mathrm{a}}$ \\
\hline Sweet potato & $6.0 \pm 2.4^{\mathrm{b}}$ & $8.2 \pm 1.8^{\mathrm{a}}$ & $8.0 \pm 2.7^{\mathrm{ab}}$ & $7.2 \pm 2.2^{\mathrm{ab}}$ & $10.7 \pm 3.4^{\mathrm{b}}$ & $6.3 \pm 2.5^{b}$ \\
\hline White bean & $4.7 \pm 3.6^{\mathrm{b}}$ & $7.2 \pm 2.3^{\mathrm{a}}$ & $6.7 \pm 3.3^{\mathrm{b}}$ & $7.7 \pm 2.2^{\mathrm{ab}}$ & $11.7 \pm 2.8^{\mathrm{ab}}$ & $8.5 \pm 1.7^{\mathrm{ab}}$ \\
\hline Starch Source & Grain & \multicolumn{2}{|c|}{ Crumb color } & \multicolumn{2}{|c|}{ Flavor } & Total Score \\
\hline Cassava & $13.5 \pm 3.1^{\mathrm{a}}$ & \multicolumn{2}{|c|}{$7.2 \pm 1.3^{\mathrm{ab}}$} & \multicolumn{2}{|c|}{$7.5 \pm 4.5^{\mathrm{a}}$} & $76.2 \pm 8.2^{\mathrm{bc}}$ \\
\hline Corn & $12.7 \pm 3.6^{\mathrm{a}}$ & \multicolumn{2}{|c|}{$7.8 \pm 1.0^{\mathrm{ab}}$} & \multicolumn{2}{|c|}{$8.3 \pm 3.9^{\mathrm{a}}$} & $76.7 \pm 7.9^{\mathrm{abc}}$ \\
\hline Potato & $14.5 \pm 2.7^{\mathrm{a}}$ & \multicolumn{2}{|c|}{$8.0 \pm 1.2^{\mathrm{ab}}$} & \multicolumn{2}{|c|}{$9.2 \pm 2.9^{\mathrm{a}}$} & $89.0 \pm 5.7^{\mathrm{ab}}$ \\
\hline Rice & $14.3 \pm 3.1^{\mathrm{a}}$ & \multicolumn{2}{|c|}{$8.3 \pm 1.4^{\mathrm{ab}}$} & \multicolumn{2}{|c|}{$9.2 \pm 2.9^{\mathrm{a}}$} & $85.0 \pm 6.8^{\mathrm{abc}}$ \\
\hline Chickpea & $14.0 \pm 3.0^{\mathrm{a}}$ & \multicolumn{2}{|c|}{$8.5 \pm 1.5^{\mathrm{ab}}$} & \multicolumn{2}{|c|}{$8.3 \pm 3.9^{\mathrm{a}}$} & $79.3 \pm 7.7^{\mathrm{abc}}$ \\
\hline Common bean & $15.0 \pm 2.3^{\mathrm{a}}$ & \multicolumn{2}{|c|}{$8.3 \pm 1.2^{\mathrm{ab}}$} & \multicolumn{2}{|c|}{$9.2 \pm 2.9^{\mathrm{a}}$} & $89.7 \pm 6.3^{\mathrm{a}}$ \\
\hline Peruvian carrot & $14.5 \pm 2.7^{\mathrm{a}}$ & \multicolumn{2}{|c|}{$8.7 \pm 1.3^{\mathrm{a}}$} & \multicolumn{2}{|c|}{$7.5 \pm 4.5^{\mathrm{a}}$} & $86.0 \pm 7.2^{\mathrm{abc}}$ \\
\hline Sweet potato & $12.7 \pm 3.6^{\mathrm{a}}$ & \multicolumn{2}{|c|}{$7.0 \pm 2.2^{b}$} & \multicolumn{2}{|c|}{$9.2 \pm 2.9^{\mathrm{a}}$} & $75.2 \pm 8.1^{\mathrm{c}}$ \\
\hline White bean & $12.0 \pm 3.6^{\mathrm{a}}$ & \multicolumn{2}{|c|}{$7.0 \pm 1.8^{\mathrm{b}}$} & \multicolumn{2}{|c|}{$9.2 \pm 2.9^{\mathrm{a}}$} & $74.5 \pm 8.4^{\mathrm{c}}$ \\
\hline
\end{tabular}

* Mean \pm standard deviation, $\mathrm{n}=12$. Cells (8-30 points): uniformity (2-10 points), size (4-10 points), thickness of walls (2-10 points); Grain (8-16 points); Texture (12-34 points): moistness (4-10 points), tenderness (4-14 points), softness (4-10 points); Crumb color (4-10 points); Flavor (0-10 points); Total Score (0-100 points). Means followed by the same lower case letter on the same column for the same parameter do not differ by the Tukey test $(\mathrm{P}<0.05)$. 
and a decrease of cohesiveness and resilience can be observed (Table 3). The cake elaborated with potato starch can be highlighted, as it did not present an increase of hardness during all the storage period and also the cake elaborated with Peruvian carrot, which maintained hardness values until day 4. In relation to springiness, some cakes showed an increase of this attribute from day 2 to day 4 and then maintained this attribute constant until day 6 (corn, potato, sweet potato and white bean) and others maintained the same springiness during all the storage period (cassava, chickpea, common bean, Peruvian carrot and rice). Another peculiarity about springiness is that it was the same for the cakes elaborated with all the starch sources studied on days 4 and 6 of storage. The cakes did not present statistical differences for springiness on these days.

The results obtained in the instrumental texture analysis had a direct relationship with the results obtained in the sensory evaluation. When hardness, chewiness and resilience results are observed, it can be seen that the cake elaborated with common bean tended to present the lowest values in relation to the cakes elaborated with the other starch sources on all the days of storage evaluated. The cake elaborated with this starch source was the cake that obtained the highest scores for the texture attributes evaluated (moisture, tenderness and softness).

As the cake elaborated with common bean, the cake elaborated with Peruvian carrot also tended to present lower values for chewiness and resilence during the storage period. It would be ideal that no increase or reduction of chewiness and resilience, respectively, occurred during storage. The cake elaborated with Peruvian carrot tended to present lower cohesiveness in relation to the others during all the storage period, which is not good. According to GÉLINAS et al. (1999), best textures were obtained when cakes showed the tendency to higher cohesiveness. The starch sources that provided the higher cake cohesiveness during all the days evaluated were cassava and rice.

For the cakes elaborated with the commercial starch sources, it can be observed that potato and rice starches presented all cake texture attribute values close to those provided by corn starch during all the storage period. Comparing the cakes elaborated with non-conventional sources and the cake elaborated with corn starch (standard commercial starch), it can be observed that chickpea and white bean were the starch sources that yielded cakes with hardness that did not differ, on days 2 and 4, from the cakes elaborated with corn starch. Chewiness and springiness attributes among the cakes elaborated with these starch sources (chickpea, white bean and corn) did not present statistical differences during all the storage period. The cohesiveness and resilience attributes also did not differ on day 2 of storage. Therefore, chickpea and white bean were the non-conventional starches that provided cake texture properties more similar to the cake elaborated with corn starch, although there are some differences. Common bean was the non-conventional starch source, followed by Peruvian carrot, which showed a propensity to be better than corn starch in some texture attributes during all the cake shelf-life. Values for hardness and chewiness attributes for cakes elaborated with common bean and Peruvian carrot did not present differences or presented better values (lower) than the cake elaborated with corn starch.

\section{CONCLUSION}

Throughout this research, it was possible to verify differences in the technological characteristics of pound cake caused by the different starch sources used in the formulation. In general, it was possible to verify that the commercial starch sources (cassava, corn, potato and rice) did not yield differences in the technological quality of the cakes in which they were applied. It demonstrated the similarity of these commercial starch sources in the application.

The non-conventional starch sources can be used to improve the characteristics of pound cake. Common bean starch, followed by Peruvian carrot starch were the non-conventional starch sources that showed a tendency to improve the technological quality of pound cake, mainly in relation to corn starch, the most used commercial source. Chickpea and white bean were the non-conventional starches that yielded cake properties more similar to the cakes elaborated with corn starch (sensory attributes, crumb moisture, texture), although there are some differences. These differences were related mainly to instrumental color and specific volume. Higher specific volumes were provided by these non-conventional sources. 
Table 3 - Texture profile analysis of cakes after two, four and six days from baking.

\begin{tabular}{|c|c|c|c|c|c|c|}
\hline \multirow{2}{*}{ Starch Source } & \multicolumn{3}{|c|}{ - } & \multicolumn{3}{|c|}{--Springiness (mm)-------------------- } \\
\hline & Day 2 & Day 4 & Day 6 & Day 2 & Day 4 & Day 6 \\
\hline Cassava & $8.56 \pm 1.02^{\mathrm{abcC}}$ & $11.87 \pm 0.45^{\mathrm{bcB}}$ & $13.42 \pm 0.69^{\mathrm{aA}}$ & $0.86 \pm 0.01^{\mathrm{aA}}$ & $0.93 \pm 0.08^{\mathrm{aA}}$ & $0.90 \pm 0.03^{\mathrm{aA}}$ \\
\hline Corn & $8.89 \pm 0.72^{\mathrm{abcC}}$ & $11.52 \pm 0.73^{\mathrm{bcA}}$ & $10.38 \pm 0.50^{\mathrm{deB}}$ & $0.83 \pm 0.01^{\mathrm{bB}}$ & $0.93 \pm 0.07^{\mathrm{aA}}$ & $0.99 \pm 0.07^{\mathrm{aA}}$ \\
\hline Potato & $9.91 \pm 0.59^{\mathrm{abA}}$ & $11.09 \pm 0.98^{\mathrm{cdA}}$ & $10.28 \pm 0.70^{\mathrm{deA}}$ & $0.82 \pm 0.01^{\mathrm{bB}}$ & $1.02 \pm 0.16^{\mathrm{aA}}$ & $0.89 \pm 0.09^{\mathrm{aAB}}$ \\
\hline Rice & $8.99 \pm 0.95^{\mathrm{abcB}}$ & $12.51 \pm 0.38^{\mathrm{abA}}$ & $12.12 \pm 0.97^{\mathrm{bcA}}$ & $0.81 \pm 0.01^{\mathrm{bA}}$ & $0.92 \pm 0.09^{\mathrm{aA}}$ & $0.89 \pm 0.07^{\mathrm{aA}}$ \\
\hline Chickpea & $8.72 \pm 0.68^{\mathrm{abcB}}$ & $11.58 \pm 0.96^{\mathrm{bcA}}$ & $11.59 \pm 0.46^{\mathrm{cA}}$ & $0.83 \pm 0.02^{\mathrm{bA}}$ & $0.88 \pm 0.07^{\mathrm{aA}}$ & $0.91 \pm 0.08^{\mathrm{aA}}$ \\
\hline Common bean & $7.95 \pm 0.73^{\mathrm{cB}}$ & $9.29 \pm 0.40^{\mathrm{eA}}$ & $9.78 \pm 0.32^{\mathrm{eA}}$ & $0.76 \pm 0.01^{\mathrm{cA}}$ & $0.88 \pm 0.12^{\mathrm{aA}}$ & $0.93 \pm 0.13^{\mathrm{aA}}$ \\
\hline Peruvian carrot & $9.17 \pm 0.72^{\mathrm{abcB}}$ & $10.08 \pm 0.81^{\mathrm{deB}}$ & $11.25 \pm 0.35^{\mathrm{cdA}}$ & $0.78 \pm 0.02^{\mathrm{cA}}$ & $0.88 \pm 0.14^{\mathrm{aA}}$ & $0.89 \pm 0.08^{\mathrm{aA}}$ \\
\hline Sweet potato & $10.01 \pm 1.13^{\mathrm{aB}}$ & $13.23 \pm 0.43^{\mathrm{aA}}$ & $12.86 \pm 0.87^{\mathrm{abA}}$ & $0.83 \pm 0.01^{\mathrm{bB}}$ & $0.85 \pm 0.07^{\mathrm{aAB}}$ & $0.93 \pm 0.08^{\mathrm{aA}}$ \\
\hline White bean & $8.49 \pm 0.70^{\mathrm{bcB}}$ & $12.12 \pm 0.54^{\mathrm{abcA}}$ & $12.41 \pm 0.60^{\mathrm{abA}}$ & $0.82 \pm 0.01^{\mathrm{bB}}$ & $0.97 \pm 0.07^{\mathrm{aA}}$ & $0.88 \pm 0.13^{\mathrm{aAB}}$ \\
\hline \multirow{2}{*}{ Starch Source } & \multicolumn{3}{|c|}{ 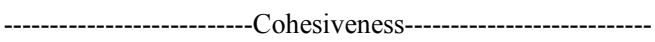 } & \multicolumn{3}{|c|}{ 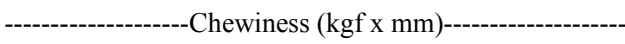 } \\
\hline & Day 2 & Day 4 & Day 6 & Day 2 & Day 4 & Day 6 \\
\hline Cassava & $0.44 \pm 0.01^{\mathrm{aA}}$ & $0.42 \pm 0.01^{\mathrm{aB}}$ & $0.41 \pm 0.01^{\mathrm{abB}}$ & $3.23 \pm 0.54^{\mathrm{abB}}$ & $4.60 \pm 0.44^{\mathrm{abA}}$ & $4.93 \pm 0.21^{\mathrm{aA}}$ \\
\hline Corn & $0.42 \pm 0.01^{\mathrm{bA}}$ & $0.41 \pm 0.01^{\mathrm{aA}}$ & $0.41 \pm 0.01^{\mathrm{aA}}$ & $3.11 \pm 0.25^{\mathrm{abB}}$ & $4.26 \pm 0.37^{\mathrm{abA}}$ & $4.24 \pm 0.24^{\mathrm{bA}}$ \\
\hline Potato & $0.42 \pm 0.01^{\mathrm{bA}}$ & $0.40 \pm 0.02^{\mathrm{bcdB}}$ & $0.41 \pm 0.01^{\mathrm{abcAB}}$ & $3.29 \pm 0.36^{\mathrm{abA}}$ & $3.78 \pm 0.53^{\mathrm{bcA}}$ & $3.39 \pm 0.44^{\mathrm{cA}}$ \\
\hline Rice & $0.42 \pm 0.01^{\mathrm{abA}}$ & $0.41 \pm 0.01^{\mathrm{abAB}}$ & $0.40 \pm 0.02^{\mathrm{abcB}}$ & $2.92 \pm 0.30^{\mathrm{abcB}}$ & $4.85 \pm 0.52^{\mathrm{aA}}$ & $4.36 \pm 0.43^{\mathrm{abA}}$ \\
\hline Chickpea & $0.40 \pm 0.01^{\mathrm{cA}}$ & $0.38 \pm 0.01^{\mathrm{deB}}$ & $0.39 \pm 0.01^{\mathrm{cdAB}}$ & $2.94 \pm 0.18^{\mathrm{abcB}}$ & $3.85 \pm 0.40^{\mathrm{bcA}}$ & $4.08 \pm 0.31^{\mathrm{bA}}$ \\
\hline Common bean & $0.39 \pm 0.01^{\mathrm{cdA}}$ & $0.38 \pm 0.01^{\mathrm{dB}}$ & $0.39 \pm 0.01^{\mathrm{bcdAB}}$ & $2.38 \pm 0.21^{\mathrm{cB}}$ & $3.17 \pm 0.49^{\mathrm{cA}}$ & $3.30 \pm 0.43^{\mathrm{cA}}$ \\
\hline Peruvian carrot & $0.38 \pm 0^{\mathrm{dA}}$ & $0.36 \pm 0.01^{\mathrm{eB}}$ & $0.36 \pm 0.01^{\mathrm{eB}}$ & $2.73 \pm 0.28^{\mathrm{bcB}}$ & $3.16 \pm 0.52^{\mathrm{cAB}}$ & $3.45 \pm 0.39^{\mathrm{cA}}$ \\
\hline Sweet potato & $0.41 \pm 0^{\mathrm{bA}}$ & $0.40 \pm 0.01^{\mathrm{abcB}}$ & $0.38 \pm 0.01^{\mathrm{deC}}$ & $3.47 \pm 0.40^{\mathrm{aB}}$ & $4.64 \pm 0.50^{\mathrm{abA}}$ & $4.48 \pm 0.45^{\mathrm{abA}}$ \\
\hline White bean & $0.41 \pm 0.01^{\mathrm{bA}}$ & $0.39 \pm 0.01^{\mathrm{cdB}}$ & $0.39 \pm 0.01^{\mathrm{bcdB}}$ & $2.89 \pm 0.24^{\mathrm{abcC}}$ & $4.60 \pm 0.29^{\mathrm{abA}}$ & $4.07 \pm 0.23^{\mathrm{bB}}$ \\
\hline Starch Source & \multicolumn{2}{|c|}{ Day 2} & \multicolumn{2}{|c|}{ Day 4} & \multicolumn{2}{|r|}{ Day 6} \\
\hline Cassava & \multicolumn{2}{|c|}{$0.21 \pm 0^{\mathrm{aA}}$} & \multicolumn{2}{|c|}{$0.20 \pm 0^{\mathrm{aB}}$} & \multicolumn{2}{|r|}{$0.20 \pm 0^{\mathrm{aB}}$} \\
\hline Corn & \multicolumn{2}{|c|}{$0.19 \pm 0^{\mathrm{bcA}}$} & \multicolumn{2}{|c|}{$0.19 \pm 0^{\mathrm{bA}}$} & \multicolumn{2}{|r|}{$0.19 \pm 0^{\mathrm{abA}}$} \\
\hline Potato & \multicolumn{2}{|c|}{$0.19 \pm 0.01^{\mathrm{bA}}$} & \multicolumn{2}{|c|}{$0.18 \pm 0.01^{\mathrm{bcB}}$} & \multicolumn{2}{|r|}{$0.18 \pm 0.01^{\mathrm{bcB}}$} \\
\hline Rice & $0.19 \pm$ & $1^{\mathrm{bcA}}$ & 0.1 & $\pm 0 \mathrm{~b}^{\mathrm{A}}$ & & $0.18 \pm 0.01^{\mathrm{cdA}}$ \\
\hline Chickpea & $0.18 \pm$ & & 0.1 & $\pm 0.01^{\mathrm{cB}}$ & & $0.17 \pm 0^{\mathrm{dB}}$ \\
\hline Common bean & $0.16 \pm$ & & 0.1 & $\pm 0 \mathrm{~d}^{\mathrm{A}}$ & & $0.16 \pm 0^{\mathrm{eA}}$ \\
\hline Peruvian carrot & $0.16 \pm$ & & 0.1 & $\pm 0^{\mathrm{dAB}}$ & & $0.15 \pm 0^{\mathrm{eB}}$ \\
\hline Sweet potato & $0.19 \pm$ & & 0.1 & $\pm 0 \mathrm{~b}^{\mathrm{A}}$ & & $0.18 \pm 0^{\mathrm{cdB}}$ \\
\hline White bean & $0.18 \pm$ & $1^{\mathrm{bcA}}$ & 0.1 & $\pm 0 c^{\mathrm{B}}$ & & $0.17 \pm 0^{\mathrm{cdB}}$ \\
\hline
\end{tabular}

* Mean \pm standard deviation, $n=6$. Means followed by the same lower case letter on the same column for the same parameter do not differ by the Tukey test $(\mathrm{P}<0.05)$. Means followed by the same upper case letter on the same row for the same parameter do not differ by the Tukey test $(\mathrm{P}<0.05)$.

\section{REFERENCES}

AACC. Approved methods of the American Association of Cereal Chemists. St Paul: Approved Methods Committee, 2010. Avalaible from: <http://methods.aaccnet.org/>. Accessed: jan 8, 2013.

AIB. Science of baking: cake and sweet goods. Manhattan: American Institute of Baking International, 2001.

BENNION, E.B.; BAMFORD, G.S.T. The technology of cake making. London: Chapman \& Hall, 1997. 421p.

GÉLINAS, P. et al. Relative effects of ingredients on cake staling based on an accelerated shelf-life test. Journal of Food Science, v.64, p.937-940, 1999. Available from: <http:// onlinelibrary.wiley.com/doi/10.1111/j.1365-2621.1999.tb15944.x/ abstract $>$. Accessed: jan. 8, 2013. doi: 10.1111/j.1365-2621.1999. tb15944.x.
GÓMEZ, M. et al. Studies on cake quality made of wheat-chickpea flour blends. LWT - Food Science and Technology, v.41, p.17011709, 2008. Available from: <http://www.sciencedirect.com/ science/article/pii/S0023643807003805>. Accessed: jan. 8, 2013. doi: 10.1016/j.lwt.2007.11.024.

HOWARD, N.B. et al. Function of the starch granule in the formation of layer cake structure. Cereal Chemistry, v.45, p.329338, 1968. Available from: <http://www.aaccnet.org/publications/cc/ backissues/1968/Documents/chem45_329.pdf $>$. Accessed: jan. 8, 2013.

LAI, H.-M.; LIN, T.-C. Bakery products. In: HUI, Y.H. Handbook of food science, technology and engineering. Boca Raton: CRC, 2006. Cap.148, p.148.1-148.51.

SAHIN, S. Cake batter rheology. In: SUMNU, S.G.; SAHIN, S. Food engineering aspects of baking sweet goods. Boca Raton: CRC, 2008. p.99-119. 
SHELKE, K. et al. The dynamics of cake baking as studied by a combination of viscometry and electrical resistance oven heating. Cereal Chemistry, v.67, p.575-580, 1990. Available from: <http://www.aaccnet.org/publications/cc/backissues/1990/ Documents/67_575.pdf>. Accessed: jan. 8, 2013.

SOZER, N. etal. Improvement of shelf life stability of cakes. Journal of Food Quality, v.34,p.151-162,2011a. Available: $<$ http://onlinelibrary. wiley.com/doi/10.1111/j.1745-4557.2011.00379.x/abstract>. Accessed: jan. 8, 2013. doi: 10.1111/j.1745-4557.2011.00379.x.
SOZER, N. et al. Textural properties and their correlation to cell structure in porous food materials. Journal of Agricultural and Food Chemistry, v.59, p.1498-1507, 2011b. Available: <http://pubs.acs.org/doi/abs/10.1021/ jf103766x $>$. Accessed em: jan. 8, 2013. doi: 10.1021/ jf103766x.

TIREKI, S. Technology of cake production. In: SUMNU, S.G.; SAHIN, S. Food engineering aspects of baking sweet goods. Boca Raton: CRC, 2008. p.149-158. 